\title{
Sistem Penerima Tamu Otomatis Pada Resepsi
}

\author{
Rahmi Eka Putri, Ibnu Harsa Anshory \\ Jurusan Sistem Komputer FTI Universitas Andalas, Kampus Unand Limau Manis Padang, Sumatera Barat 25163 Indonesia
}

\section{ARTICLE INFORMATION}

Received: August $28^{\text {th }}, 2019$

Revised: September $27^{\text {th }}, 2019$

Available online: October $10^{\text {th }}, 2019$

\section{KEYWORDS}

RFID, penerima tamu, resepsi, souvenir otomatis

\section{CORRESPONDENCE}

Phone: +62 (751) 71181

E-mail: rahmi@fti.unand.ac.id

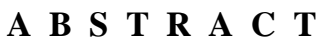

Wedding reception is an event that is attended by invited guests. When entering the reception, guests will be welcomed by a guest waiting who will invite guests to fill in the guest book and give souvenirs to guests. At a reception that invites a lot of guests will cause a queue of guests at the reception entrance due to time to write down names and addresses in the guest book. In this study an automatic reception system was designed at the reception by reading the RFID tag that affixed to the RFID reader and storing guest data to the SD card and then souvenirs will come out automatically. With this system, processing time is shorter and guest data that comes can be stored and displayed through notepad. The test results show the system can read and store guest data with a success rate of $100 \%$, with an average maximum distance of RFID tags and RFID reader $2.5 \mathrm{~cm}$. Overall testing of the system resulted in 2 out of 10 unsuccessful attempts due to souvenirs stuck to the souvenir holder, but guest data was successfully stored in accordance with the RFID tag affixed to the RFID reader.

\section{INTRODUCTION}

Resepsi merupakan suatu pesta yang di hadiri oleh para undangan atau tamu undangan[1] yang bertujuan untuk mengumumkan pelaksanaan pernikahan dan sebagai momen silaturahmi untuk berbagi kebahagiaan. Sebelum memasuki sebuah acara resepsi biasanya tamu akan disambut oleh penerima tamu yang bertugas untuk mempersilahkan tamu mengisi buku tamu dan memberikan souvenir kepada tamu. Secara konvesional, tamu undangan mengisi buku tamu dengan menuliskan nama dan alamat pada buku tamu dan penerima tamu akan memberikan souvenir kepada tamu. Proses ini membutuhkan waktu yang cukup banyak untuk masing-masing tamu undangan. Pada acara resepsi dengan jumlah tamu yang cukup banyak, hal ini dapat menyebabkan penumpukan antrean tamu di depan pintu masuk acara resepsi.

Perkembangan teknologi informasi saat ini telah banyak digunakan untuk memberikan kemudahan, mempercepat dan mengefisienkan pekerjaan. saat ini banyak peran manusia yang di gantikan oleh alat-alat dan mesin otomatis. Otomatisasi artinya sebuah proses dapat bekerja sendiri tanpa bantuan manusia [2]. Dalam penelitian ini sistem otomatis dapat diterapkan pada acara resepsi dengan membuat sebuah sistem penerima tamu otomatis yang terdiri dari proses penyimpanan data tamu menggunakan teknologi RFID (Radio Frequency Identification) untuk menggantikan proses menulis data tamu pada buku tamu dan pemberian souvenir secara otomatis kepada para tamu. Tamu undangan cukup menempelkan RFID tag yang sudah disertakan sebelumnya dalam undangan resepsi ke RFID reader yang dipasang pada sistem. Sistem akan membaca data tamu pada RFID tag dan menyimpan data tamu tersebut kemudian sistem akan memberikan souvenir kepada tamu secara otomatis.

Pada penelitian [3] sebelumnya telah membahas tentang sistem yang dapat mengurangi waktu antri setiap penumpang pada saat melakukan check in di bandara dengan menggunakan teknologi RFID. Penelitian lainnya [4] telah membahas tentang sistem yang dapat mengeluarkan barang di minimarket yang telah dipesan sebelumnya secara otomatis. Pada penelitian ini, data tamu dapat disimpan menggunakan teknologi RFID dengan cara menempelkan RFID tag ke RFID reader, juga ditambahkan dengan adanya pemberian souvenir otomatis kepada para tamu, sehingga dapat mengurangi waktu dan antrean para tamu undangan di pintu masuk acara resepsi.

\section{Radio Frequency Identification (RFID)}

RFID adalah teknologi identifikasi yang fleksibel, mudah digunakan, dan sangat cocok untuk operasi otomatis. Pada sistem RFID umumnya, tag atau transponder ditempelkan pada suatu objek. Setiap tag membawa dapat membawa informasi yang unik, di antaranya: serial number, model, warna, tempat perakitan, dan data lain dari objek tersebut [5]. Ketika tag ini melalui medan yang dihasilkan oleh pembaca RFID yang kompatibel, tag akan mentransmisikan informasi yang ada pada tag kepada pembaca RFID, sehingga proses identifikasi objek dapat dilakukan [5]. 


\section{RFID Reader}

RFID tag (transponder) yang terdiri dari sebuah device yang kecil yang tertanam dalam sebuah buku seperti label, smartcard dan lainya yang memiliki identifikasi yang unik dan memori yang dapat di tulis[6]. RFID tag akan mengenali diri sendiri ketika mendeteksi sinyal dari perangkat yang hanya dapat dibaca saja (Read only) dibaca dan ditulis (Read/Write) sekali tulis dan banyak baca (write once read many) juga tidak memerlukan kontak langsung maupun jalur cahaya untuk dapat beroperasi. RFID dapat berfungsi pada berbagai variasi kondisi lingkungan dan menyediakan tingkat integritas data yang tinggi. Selama ini sistem otomatis yang dikenal sistem barcode mempunyai keterbatasan dalam penyimpanan data serta yang tersimpan didalamnya [6].

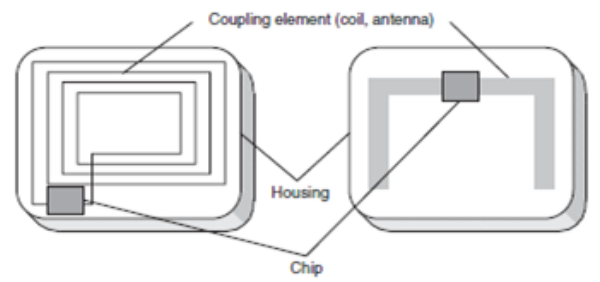

Gambar 1. Klasifikasi Tampilan RFID atau Transponder[6]

\section{RFID Reader}

Untuk berfungsinya sistem RFID diperlukan sebuah scanning device atau reader yang dapat membaca tag dengan benar dan mengkomunikasikan hasilnya bagi yang membutuhkan informasi. Reader menggunakan antena terpasang untuk menangkap data dari tag. Kemudian mengirim data ke komputer untuk diproses [6]. Salah satu contoh dari RFID reader adalah MFRC522 Reader Module yang dapat dilihat pada Gambar 2.

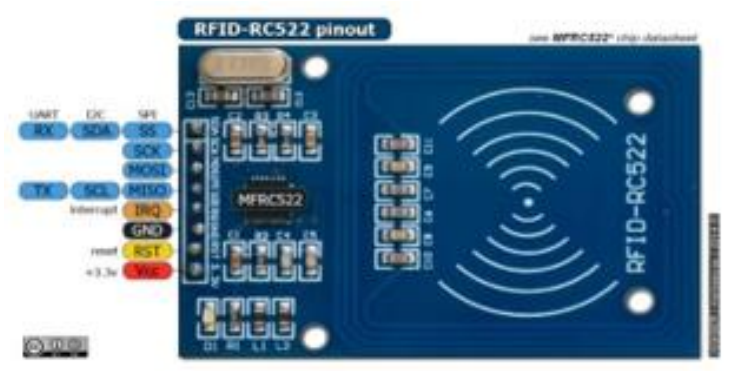

Gambar 2. RFID Reader [6]

\section{Mikrokontroler Arduino Mega 2560}

Arduino Mega 2560 adalah papan mikrokontroler berdasarkan ATmega2560. Ia memiliki 54 pin input / output digital (15 di antaranya dapat digunakan sebagai output PWM), 16 input analog, 4 UART (port serial perangkat keras), osilator kristal 16 $\mathrm{MHz}$, koneksi USB, colokan listrik, header ICSP, dan tombol reset. Ini berisi semua yang diperlukan untuk mendukung mikrokontroler, cukup sambungkan ke komputer dengan kabel USB atau daya dengan adaptor AC-ke-DC atau baterai untuk memulai. Papan Mega 2560 kompatibel dengan sebagian besar perisai yang dirancang untuk Uno dan papan sebelumnya Duemilanove atau Diecimila [7]. Arduino Mega dapat dilihat pada gambar 3 .

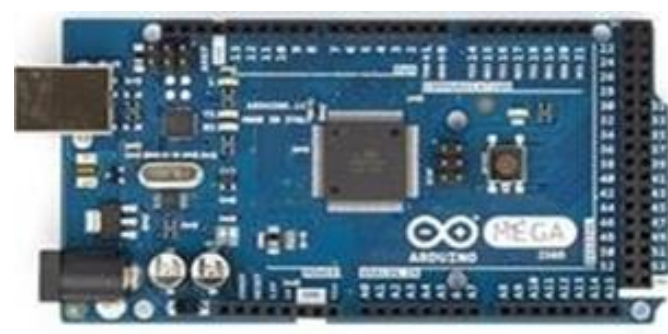

Gambar 3. Arduino Mega [7]

\section{Sensor Infrared}

Sensor infrared adalah komponen adalah komponen elektronika yang dapat mendeteksi benda ketika cahaya infra merah yang terhalangi oleh benda. Sensor infrared terdiri dari LED infrared sebagai pemancar dan fototransistor sebagai penerima cahaya infra merah. $L E D$ infrared sebagai pemancar cahaya infra merah merupakan singkatan dari Light Emitting Diode Infrared yang terbuat dari bahan Galium Arsenida (GaAs) dapat memancarkan cahaya infra merah dan radiasi panas saat diberi energi listrik [8]. Proses pemancaran cahaya akibat adanya energi listrik yang diberikan terhadap suatu bahan disebut dengan sifat elektroluminesensi. Gambar $L E D$ infrared dapat dilihat pada gambar 4.

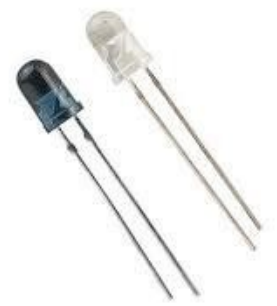

Gambar 4 LED Infrared [8]

\section{Motor Servo}

Motor servo adalah motor yang mampu bekerja dua arah yaitu Clockwise (CW) dan Counter Clockwise (CCW) dimana arah dan sudut pergerakan rotornya dapat dikendalikan hanya dengan memberikan pengaturan duty cycle sinyal PWM pada bagian pin kontrolnya. Motor servo memiliki 3 kabel yaitu Power, Ground, Control, berikut merupakan gambar motor servo [9]. Gambar motor servo dapat dilihat pada gambar 5 .

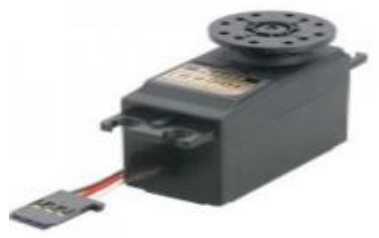

Gambar 5 Motor Servo [9]

\section{LCD (Liquid Cristal Display)}

LCD (Liquid Cristal Display) adalah salah satu jenis display elektronik yang dibuat dengan teknologi CMOS logic yang bekerja dengan tidak menghasilkan cahaya tetapi memantulkan cahaya yang ada di sekelilingnya terhadap front-lit atau mentransmisikan cahaya dari back-lit. LCD berfungsi sebagai penampil data baik dalam bentuk karakter, huruf, angka ataupun grafik. LCD adalah lapisan dari campuran organik antara lapisan kaca bening dengan elektroda transparan indium oksida dalam 
bentuk tampilan seven-segment dan lapisan elektroda pada kaca belakang. Ketika elektroda diaktifkan dengan medan listrik (tegangan), molekul organik yang panjang dan silindris menyesuaikan diri dengan elektroda dari segmen. Lapisan sandwich memiliki polarizer cahaya vertikal depan dan polarizer cahaya horisontal belakang yang diikuti dengan lapisan reflektor. Cahaya yang dipantulkan tidak dapat melewati molekul-molekul yang telah menyesuaikan diri dan segmen yang diaktifkan terlihat menjadi gelap dan membentuk karakter data yang ingin ditampilkan[10]. LCD dapat dilihat pada gambar 6.

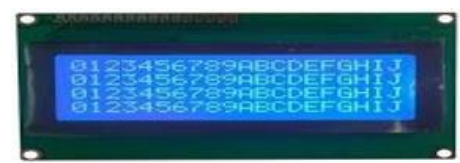

Gambar 6. LCD (Liquid Crystal Display) [10]

\section{Buzzer}

Buzzer adalah sebuah komponen elektronika yang berfungsi untuk mengubah getaran listrik menjadi getaran suara getaran listrik menjadi getaran suara. Pada dasarnya prinsip kerja buzzer hampir sama dengan loudspeaker, jadi buzzer juga terdiri dari kumparan yang terpasang pada diafragma dan kemudian kumparan tersebut dialiri arus sehingga menjadi elektromagnet, kumparan tadi akan tertarik ke dalam atau keluar, tergantung dari arah arus dan polaritas magnetnya, karena kumparan dipasang pada diafragma maka setiap gerakan kumparan akan menggerakkan diafragma secara bolak-balik sehingga membuat udara bergetar yang akan menghasilkan suara. Buzzer biasa digunakan sebagai indikator bahwa proses telah selesai atau terjadi suatu kesalahan pada sebuah alat (alarm)[10]. Buzzer dapat dilihat pada gambar 7 .

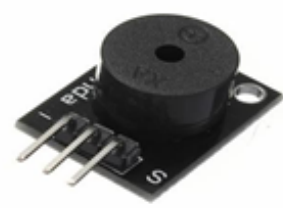

Gambar 7. Buzzer [10]

\section{Arduino IDE}

Pemograman ini dalah pemograman bawaan dari mikrokontroller arduino uno, yaitu Arduino IDE. Arduino IDE merupakan sebuah perangkat lunak yang memudahkan dalam pembuatan program dan mengupload program tersebut kedalam board Arduino[10]. Tampilan arduino IDE dapat dilihat pada gambar 8.

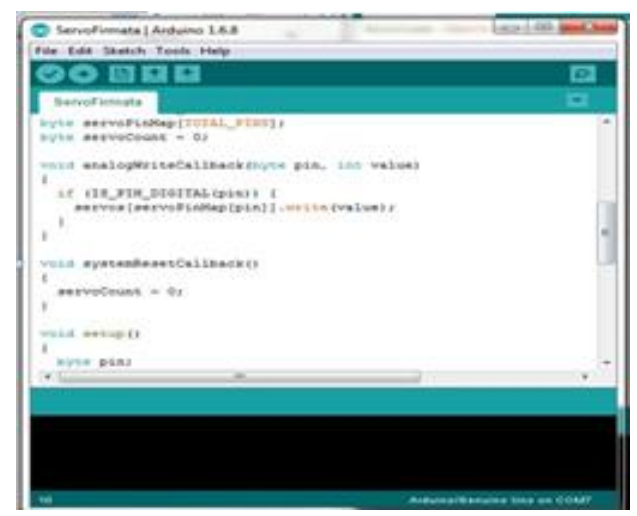

Gambar 8. Tampilan Arduino IDE

\section{METODOLOGI PENELITIAN}

Metode penelitian yang digunakan dalam penulisan tugas akhir ini adalah penelitian eksperimental (Experimental Research). Metode penelitian dibutuhkan sebagai dasar dalam melakukan penelitian agar tercapai tujuan penelitian yang telah ditetapkan. Metode yang digunakan dalam penelitian ini dapat dilihat pada gambar 9 yang berisi tahapan-tahapan penelitian, dimulai dari identifikasi masalah sampai dokumentasi penelitian.

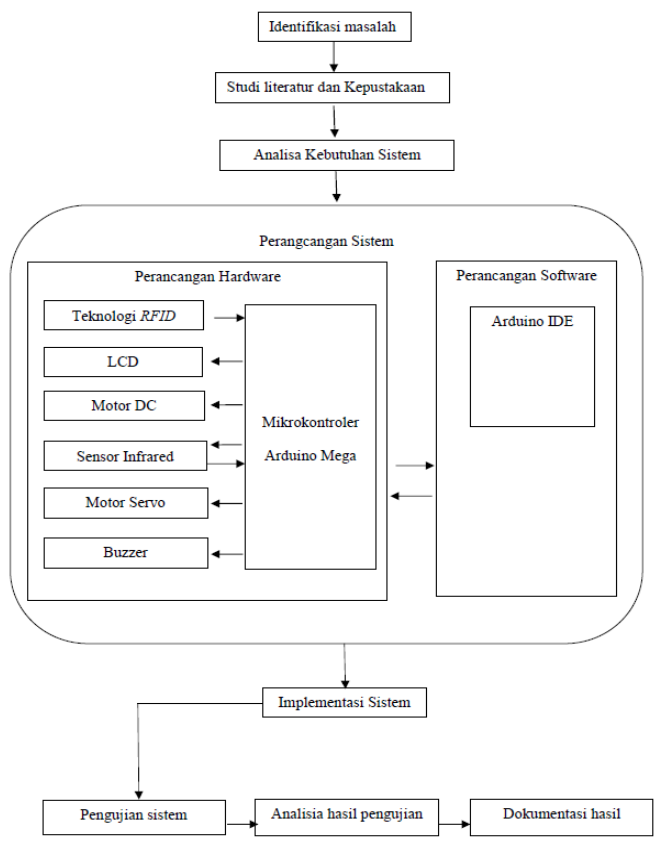

Gambar 9 Metodologi Penelitian

Pada penelitian ini dilakukan penghubungan komponen alat-alat yang berbeda karakteristik. Komponen dan alat-alat tersebut antara lain adalah RFID reader, sensor ultrasonik, motor servo, dan arduino uno. Pada penelitian ini sistem akan diuji apakah masukan yang diberikan apakah sesuai dengan keluaran yang diinginkan.

\section{Perancangan Sistem}

Perancangan sistem dibuat untuk menggambarkan sistem yang akan dibuat. Dalam penelitian ini digunakan beberapa perangkat keras dalam perancangannya yaitu :

\section{RFID}

Terbagi atas RFID tag dan RFID reader, RFID tag sebagai penginput id dan RFID reader sebagai pembaca id yang mengirim perintah kepada mikrokontroler.

2. Sensor infrared

Sebagai pembaca ketersediaan souvenir, membaca dengan cara apabila ada benda yang menghangi.

3. Mikrokontroler arduino mega

Arduino berfungsi sebagai mikrokontroler yang menjadi pengontrol utama dari sistem yang nantinya akan mengolah masukan yang telah dibaca oleh sensor dan RFID reader.

4. Motor servo

Motor servo berfungsi sebagai alat yang akan memberikan output untuk mengeluarkan souvenir.

5. Motor DC 
Motor DC berfungsi sebagai pendorong souvenir

6. LCD

LCD berfungsi sebagai output tampilan nama tamu yang hadir.

7. Buzzer

Buzzer berfungsi sebagai output penanda bahwa stok souvenir akan habis.

Rancangan umum sistem dapat dilihat pada gambar 10.

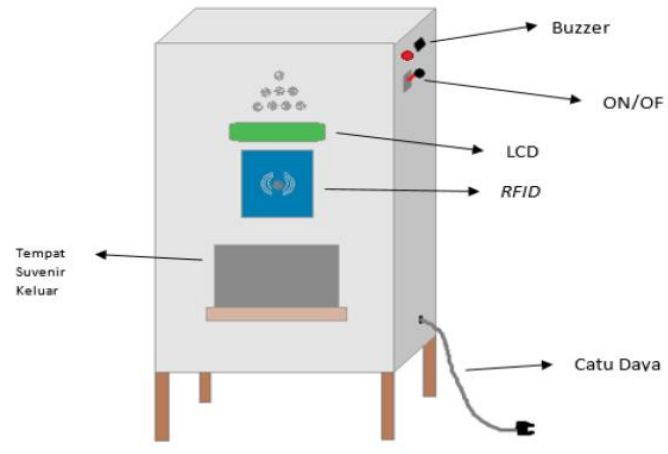

Gambar 10 Rancangan Sistem

\section{Rancangan Proses}

Rancangan proses dalam penelitian ini terdiri dari beberapa tahapan yang dapat dilihat pada gambar 11

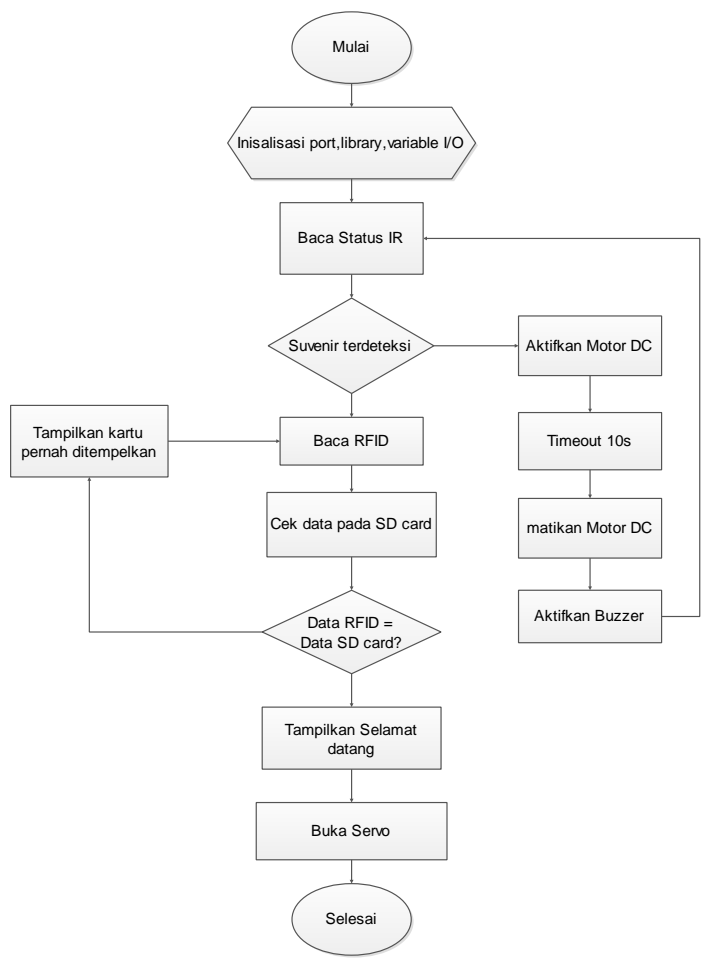

Gambar 11. Rancangan Proses

Rancangan proses pada penelitan ini yaitu:

1. Inisialisasi dan deklarasi variabel input/output

2. Baca Infrared

Apabila ada souvenir terdeteksi oleh souvenir maka kerjakan perintah selanjutnya

3. Aktifkan Motor DC
Jalanjan motor DC selama waktu yang telah di tentukan, apabilla dalam kurun waktu tersebut, infrared masih belum mendeteksi souvenir maka kerjakan perintah selanjutnya.

4. Aktifkan Buzzer

Buzzer akan hidup ketika infrared masih belum mendeteksi souvenir pada waktu yang telah di tetapkan.

5. Baca RFID

Apabila souvenir terbaca oleh Infrared, maka baca RFID dan kerjakan perintah selanjutnya.

6. Apabila RFID terdeteksi makan baca SD Card

7. Apabila data pada RFID sudah ada pada SD Card maka LCD akan menampilkan kalimat "Kartu pernah di tempelkan".

8. Jika data pada RFID tidak sama dengan SD Card maka Tampilkan di LCD kaliman "Selamat Datang"

9. Servo akan terbuka untuk menjatuhkan souvenir dann tertutup kembali

10. Data RFID akan di catat di SD Card

\section{HASIL DAN PEMBAHASAN}

Rancangan sistem penerima tamu otomatis pada resepsi yang telah dibuat pada tahap sebelumnya diimplementasikan. Implementasi yang dilakukan terdiri dari tiga bagian yaitu implementasi perangkat keras, implementasi perangkat lunak dan implementasi sistem secara keseluruhan yang bertujuan untuk mengetahui apakah sistem dapat berjalan dengan baik dan sesuai dengan tujuan penelitian.

\section{Implementasi Perangkat Keras}

Implementasi perangkat keras terdiri dari beberapa komponen yang di susun dalam sebuah akrilik berbentuk kotak yang memiliki dimensi panjang $30 \mathrm{~cm}$, lebar $30 \mathrm{~cm}$ dan tinggi $45 \mathrm{~cm}$. Implementasi perangkat keras dapat dilihat pada gambar 12.
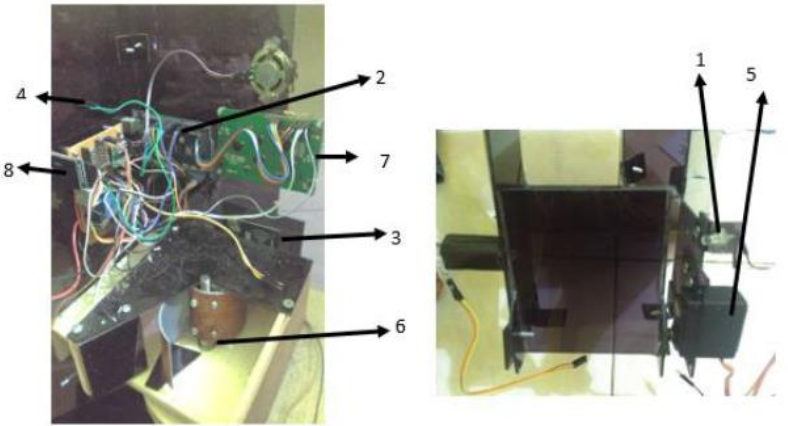

Gambar 12. Implementasi Perangkat Keras Sistem

Komponen - komponen perangkat keras yang digunakan dalam sistem ini sesuai gambar 12 yaitu:

1. Sensor Infrared berfungsi untuk mendeteksi souvenir.

2. Arduino Mega berfungsi sebagai mikrokontroller yang digunakan pada alat.

3. RFID RC522 berfungsi sebagai pembaca ID dari tag undangan.

4. Buzzer sebagai notifikasi suara jika souvenir sudah habis.

5. Motor servo sebagai output penggerak buka tutup mengeluarkan souvenir.

6. Motor DC sebagai output penggerak alat pendorong souvenir. 
7. LCD sebagai output penampil data.

8. SD Card Sebagai media penyimpanan data tamu.

\section{Implementasi Perangkat Lunak}

Implementasi perangkat lunak pada sistem ini berupa pemrograman mikrokontroler yang dibuat dengan Arduino IDE. Program dibuat agar perangkat keras dapat berjalan sesuai dengan rancangan yang sudah dibut sebelumnya. Salah satu program yang digunakan adalah program menyimpan data tamu pada SD Card dapat dilihat pada gambar 13.

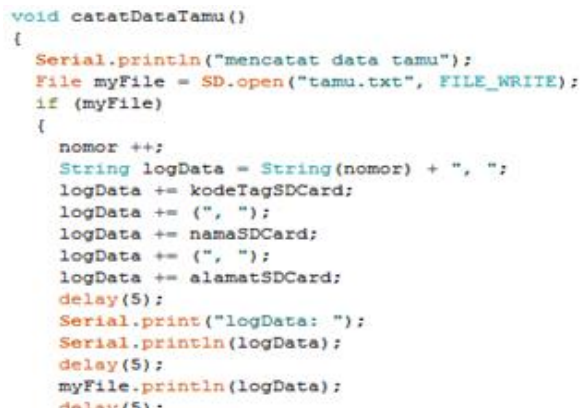

Gambar 13. Program menyimpan data tamu pada SD Card

\section{Implementasi Sistem}

Pada implementasi sistem ini akan dilakukan penggabungan antara perangkat keras dan perangkat lunak menjadi suatu sistem yang dapat membaca dan menyimpan data tamu undangan serta dapat mengeluarkan souvenir secara otomatis.

\section{Implementasi Tampilan Pada LCD}

Pada saat tamu menempelkan RFID tag pada alat, sistem akan memberikan pesan yang akan ditampilkan pada LCD. Implementasi program dan tampilan LCD ketika RFID tag ditempelkan dapat dilihat pada gambar 14, implementasi program dan tampilan LCD jika RFID tag ditempelkan lebih dari satu kali dapat dilihat pada gambar 15 serta implementasi program dan tampilan LCD ketika souvenir yang disimpan pada tempat penampung souvenir telah habis dapat dilihat pada gambar 16 .
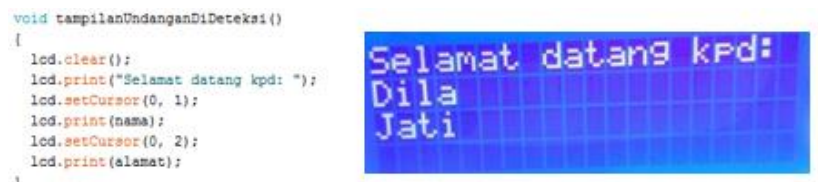

Gambar 14. Implementasi program dan tampilan LCD ketika RFID tag ditempelkan
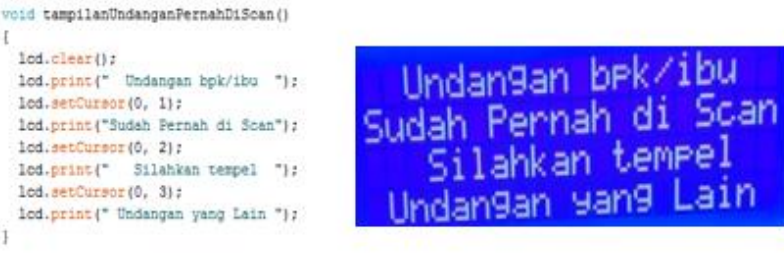

Gambar 15. Implementasi program dan tampilan LCD jika RFID tag ditempelkan lebih dari satu kali

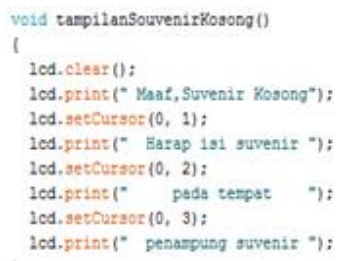

Gambar 16. Implementasi program dan tampilan LCD ketika souvenir yang disimpan pada tempat penampung souvenir telah habis

\section{Implementasi Data Tamu Yang Hadir}

Pada saat RFID tag ditempelkan ke alat, data tamu yang ada pada RFID tag dibaca dan disimpan ke dalam SD card. Data tamu yang telah disimpan dalm SD card dapat dilihat untuk mengetahui tamu yang hadir memenuhi undangan resepsi. Tampilan data tamu yang hadir dapat dilihat pada gambar 17.

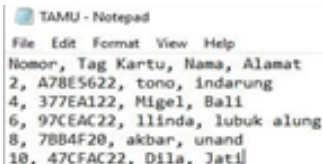

Gambar 17. Tampilan notepad data tamu yang hadir

\section{Pengujian dan Analisa Perangkat Keras}

Pengujian perangkat keras dilakukan untuk memastikan masingmasing bagian dari sistem bekerja dengan baik demi tercapainya tujuan dari penelitian tugas akhir ini. Pengujian yang dilakukan terdiri dari pengujian RFID, motor servo dan buzzer.

\section{Pengujian RFID RC522}

RFID berfungsi untuk membaca data tamu undangan yang hadir pada acara resepsi. Pengujian RFID RC522 dilakukan dengan cara menempelkan kartu tag yang berbeda-beda pada RFID RC522 untuk menguji keakuratan RFID reader. Pengujian pembacaan RFID reader dapat dilihat pada tabel 1.

Tabel 1. Pengujian pembacaan RFID reader

\begin{tabular}{|c|c|c|c|}
\hline Kartu & Percobaan & ID yang didapatkan & Kesimpulan \\
\hline \multirow[t]{2}{*}{1} & Percobaan 1 & C38650A3 & \multirow{2}{*}{ ID Sama } \\
\hline & Percobaan 2 & C38650A3 & \\
\hline \multirow[t]{2}{*}{2} & Percobaan 1 & C7685922 & \multirow{2}{*}{ ID Sama } \\
\hline & Percobaan 2 & C7685922 & \\
\hline \multirow[t]{2}{*}{3} & Percobaan 1 & B8EE6D & \multirow{2}{*}{ ID Sama } \\
\hline & Percobaan 2 & B8EE6D & \\
\hline \multirow[t]{2}{*}{4} & Percobaan 1 & A78E5622 & \multirow{2}{*}{ ID Sama } \\
\hline & Percobaan 2 & A78E5622 & \\
\hline \multirow[t]{2}{*}{5} & Percobaan 1 & 97CEAC22 & \multirow[b]{2}{*}{ ID Sama } \\
\hline & Percobaan 2 & $97 C E A C 22$ & \\
\hline
\end{tabular}

Berdasarkan hasil pengujian pembacaan RFID reader pada Tabel 1, dapat dilihat setelah 10 kali percobaan menggunakan 5 kartu yang berbeda mendapatkan nilai ID yang tidak berubah, dimana 
tidak didapat hasil yang menunjukan kegagalan pembacaan ID. Hasil ini menunjukan tingkat keakuratan dari RFID reader adalah $100 \%$.

Selanjutnya dilakukan pengujian RFID RC522 dengan cara mendekatkan RFID tag pada reader dengan tujuan agar diketahui jarak pembacaan optimal oleh reader terhadap RFID tag. Pengujian ini dilakukan tanpa adanya halangan antara RFID tag dan RFID reader. Dalam melakukan pengujian ini dilakukan dengan 8 kali pengujian dengan jarak yang berbeda menggunakan 5 RFID tag seperti terlihat pada tabel 2.

Tabel 2. Pengujian jarak pembacaan RFID reader

\begin{tabular}{|c|c|c|c|c|c|}
\hline \multirow{2}{*}{ Jarak Baca } & \multicolumn{6}{|c|}{ Tag Kartu } \\
\cline { 2 - 6 } & A1 & A2 & A3 & A4 & A5 \\
\hline $0,5 \mathrm{~cm}$ & $\checkmark$ & $\checkmark$ & $\checkmark$ & $\checkmark$ & $\checkmark$ \\
\hline $1 \mathrm{~cm}$ & $\checkmark$ & $\checkmark$ & $\checkmark$ & $\checkmark$ & $\checkmark$ \\
\hline $1,5 \mathrm{~cm}$ & $\checkmark$ & $\checkmark$ & $\checkmark$ & $\checkmark$ & $\checkmark$ \\
\hline $2 \mathrm{~cm}$ & $\checkmark$ & $\checkmark$ & $\checkmark$ & $\checkmark$ & $\checkmark$ \\
\hline $2,5 \mathrm{~cm}$ & $\times$ & $\checkmark$ & $\checkmark$ & $\checkmark$ & $\checkmark$ \\
\hline $3 \mathrm{~cm}$ & $\times$ & $\times$ & $\times$ & $\checkmark$ & $\times$ \\
\hline $3,5 \mathrm{~cm}$ & $\times$ & $\times$ & $\times$ & $\times$ & $\times$ \\
\hline $4 \mathrm{~cm}$ & $\times$ & $\times$ & $\times$ & $\times$ & $\times$ \\
\hline
\end{tabular}

Keterangan :

A1 : 658558213

A2 : 221715202

A3 : C38650A3

A4 : A78E5622

A5 : 97CEAC22

$\checkmark=$ Terbaca

$x=$ Tidak Terbaca

Pengujian terhadap jarak dilakukan dengan mengubah jarak antara RFID tag dengan RFID reader sehingga diketahui jarak baca maksimum dari RFID tersebut. Jarak jangkauan tag terbaca oleh reader yang diperoleh pada penelitian ini sebesar $3 \mathrm{~cm}$ yaitu pada tag dengan ID A78E5622 (A4). Pada tag dengan ID lainnya 221715202 (A2), C38650A3 (A3) dan 97CEAC22 (A5) jarak baca maksimum yang diperoleh yaiyu $2,5 \mathrm{~cm}$. Sedangkan pada tag dengan ID 658558213 (A1) jarak baca maksimum hanya 2 $\mathrm{cm}$. Jarak baca RFID tag ini dipengaruhi oleh antena yang terdapat pada chip mikro RFID.

\section{Pengujian Motor Servo}

Pengujian dilakukan dengan bantuan busur derajat guna mengetahui besar pergeseran dari motor servo. Pada program arduino motor servo disetting melakukan penambahan derajat sebesar $45^{\circ}$ dengan waktu delay $3000 \mathrm{~ms}$ (3 detik). Setelah motor servo mencapai sudut $180^{\circ}$ maka motor servo akan melakukan pengurangan derajat sebesar $45^{\circ}$ hingga kembali pada posisi $0^{\circ}$. Penggunaan waktu delay sebesar 3 detik guna memberi waktu untuk mengamati besar perubahan motor servo. Hasil pengujian motor servo dapat dilihat pada tabel 3.

Tabel 3 Hasil pengujian motor servo

\begin{tabular}{|c|c|c|}
\hline $\begin{array}{c}\text { Sudut yang } \\
\text { diinginkan }\end{array}$ & $\begin{array}{c}\text { Pembacaan } \\
\text { busur derajat }\end{array}$ & Error (\%) \\
\hline $0^{\circ}$ & $0^{\circ}$ & $0 \%$ \\
\hline $45^{\circ}$ & $50^{\circ}$ & $11,11 \%$ \\
\hline $90^{\circ}$ & $90^{\circ}$ & $0 \%$ \\
\hline $135^{\circ}$ & $140^{\circ}$ & $3,7 \%$ \\
\hline $180^{\circ}$ & $190^{\circ}$ & $5,56 \%$ \\
\hline \multicolumn{2}{|c|}{ Rata-rata error } & $4,07 \%$ \\
\hline
\end{tabular}

Berdasarkan hasil pengujian motor servo pada tabel 3, didapatkan rata-rata error sebesar $4,07 \%$.

\section{Pengujian Buzzer}

Pengujian buzzer dilakukan untuk mengetahui apakah buzzer mampu bekerja sesuai intruksi yang diperintahkan oleh mikrokontroler, pada penelitian ini buzzer difungsikan sebagai pemberi indikator suara alarm bahwa souvenir telah habis. Hasil pengujian buzzer dapat dilihat pada tabel 4 .

Tabel 4. Hasil pengujian buzzer

\begin{tabular}{|c|c|c|c|}
\hline Data Ke- & Nilai Pin & Kondisi Buzzer & Status \\
\hline 1 & 1 (High) & Hidup & Berhasil \\
\hline 2 & 0 (Low) & Mati & Berhasil \\
\hline 3 & 1 (High) & Hidup & Berhasil \\
\hline 4 & 0 (Low) & Mati & Berhasil \\
\hline 5 & 1 (High) & Hidup & Berhasil \\
\hline 6 & 0 (Low) & Mati & Berhasil \\
\hline
\end{tabular}

Berdasarkan hasil pengujian buzzer pada tabel 4, didapatkan keberhasilan sebesar $100 \%$.

\section{Pengujian dan Analisa Perangkat Lunak}

Pengujian perangkat lunak dilakukan terhadap arduino IDE yang digunakan sebagai tempat pembuatan program dan pengujian pengiriman data. Pengiriman data dapat dilihat pada serial monitor yang ada pada aplikasi Arduino IDE. Pada serial monitor tersebut ditampilkan hasil pembacaan RFID reader. Pada pengujian program di aplikasi arduino IDE, semua perangkat yang digunakan dideklarasikan terlebih dahulu. Mulai dari pemakaian pin sampai ke inisialisasi posisi awal. Ketika sistem dinyalakan, pengiriman data akan ditampilkan pada serial monitor. Tampilan pembacaan RFID tag pada serial monitor dapat dilihat pada gambar 18.

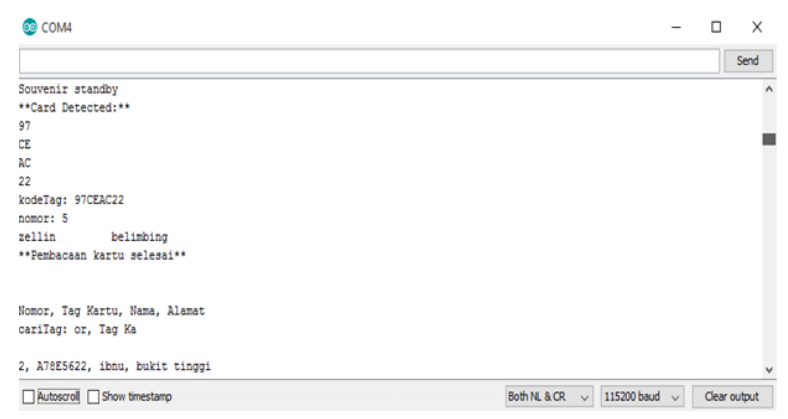

Gambar 18. Tampilan pembacaan RFID tag pada serial monitor 


\section{Pengujian dan Analisa Sistem Secara Keseluruhan}

Pengujian sistem secara keseluruhan bertujuan untuk memastikan apakah sistem dapat bekerja sesuai dengan fungsinya untuk membaca dan menyimpan data tamu serta memberikan souvenir secara otomatis kepada para tamu berdasarkan RFID tag yang dibaca. Pengujian ini yang terdiri dari beberapa komponen yaitu, RFID reader, LCD, motor DC, motor Servo, sensor infrared, buzzer dan modul SD Card dengan menggunakan 10 kali percobaan menggunakan RFID tag yang berbeda-beda. Hasil Pengujian keseluruhan dapat dilihat pada tabel 5.

Tabel 5. Hasil pengujian sistem secara keseluruhan

\begin{tabular}{|c|c|c|c|l|l|l|c|c|}
\hline $\begin{array}{c}\text { Penguji } \\
\text { an ke- }\end{array}$ & RFID & LCD & $\begin{array}{c}\text { Motor } \\
\text { DC }\end{array}$ & Servo & IR & Buzzer & $\begin{array}{c}\text { SD } \\
\text { Card }\end{array}$ & $\begin{array}{c}\text { Souvenir } \\
\text { keluar }\end{array}$ \\
\hline 1 & Terbaca & Tampil & On & On & On & Off & Save & Ya \\
\hline 2 & Terbaca & Tampil & On & On & On & Off & Save & Ya \\
\hline 3 & Terbaca & Tampil & On & Off & Off & On & Save & Tidak \\
\hline 4 & Terbaca & Tampil & On & On & On & Off & Save & Ya \\
\hline 5 & Terbaca & Tampil & On & On & On & Off & Save & Ya \\
\hline 6 & Terbaca & Tampil & On & Off & Off & On & Save & Tidak \\
\hline 7 & Terbaca & Tampil & On & On & On & Off & Save & Ya \\
\hline 8 & Terbaca & Tampil & On & On & On & Off & Save & Ya \\
\hline 9 & Terbaca & Tampil & On & On & On & Off & Save & Ya \\
\hline 10 & Terbaca & Tampil & On & On & On & Off & Save & Ya \\
\hline
\end{tabular}

Berdasarkan hasil pengujian sistem secara keseluruhan pada tabel 5, diperoleh hasil dari 10 kali percobaan terdapat 2 kali percobaan yang tidak berhasil yaitu pada percobaan ke 3 dan percobaan ke 6. Hal ini disebabkan souvenir yang tersangkut pada alat pendorong souvenir atau penampung souvenir sehingga souvenir tidak dapat keluar dari alat. Namun data tamu berhasil disimpan sesuai dengan RFID tag yang didekatkan ke RFID reader.

\section{KESIMPULAN}

Berdasarkan dari penelitian dan pengujian yang dilakukan, dapat disimpulkan bahwa:

1. Sistem dapat membaca dan menyimpan data tamu yang hadir pada acara resepsi menggunakan RFID RC522 dengan cara menempelkan RFID yang berisi data tamu ke RFID reader.

2. Sistem dapat mengeluarkan souvenir secara otomatis dengan membuka motor servo ketika tamu menempelkan RFID tag ke RFID reader.

3. Sistem dapat memberitahukan souvenir habis dengan bunyi dari buzzer ketika sensor infrared tidak mendeteksi adanya halangan berupa souvenir.

4. Data Tamu undangan yang hadir disimpan pada SD Card dan dapat kita lihat menggunakan Notepad.

\section{DAFTAR PUSTAKA}

[1] Purwadi, 2004. Tata Cara Pernikahan Pengantin Jawa. Media Abadi. Yogyakarta.

[2] Satria, Fazri. 2014. Perancangan Sistem Otomasi Terpadu Berbasisnirkabel Pada Stasiun Kerja X,Y,Z Di Pt.Abc .
Teknis Industri. Fakultas Rekayasa Industri. Universitas Telkom

[3] Pradipta, Gede Angga. 2015. Perancangan Sistem Otomatisasi Check In Passanger Pada Airport Berbasis Teknologi Passive RFID. STMIK STIKOM Bali.

[4] Wibowo, Taufik Akbar. 2019. Proptotype Smart Minimarket, JITCE Vol 03 No.01

[5] Suada, Cendy. 2016. Perancangan Dan Implementasi Sistem Penyortiran Dan Penghitungan Barang Menggunakan Teknologi RFID (Radio Frequency Identification). Sistem Komputer. Fakultas Teknologi Informasi. Universitas Andalas

[6] Saeful Bahri, Suhardiyanto, Sistem Keamanan Ruang Server Menggunakan Teknologi RFID Dan Password, Jurnal Elektum, volume 15, No.1, ISSN 1979- 5564, 2018

[7] Sulham Setiawan, Mudah Menyenangkan Belajar Arduino. Yoogyakarta, 2006.

[8] Susilo, Anto. 2009. Sistem Sensor Inframerah . Jakarta : Bumi Aksara

[9] Sigit, Riyanto dkk. 2007. "Motor Servo". Politeknik Negeri Surabaya-ITS. Surabaya.

[10] R. Setiawan, Mikrokontroler MCS-51, Graha Ilmu. Yogyakarta. 